\title{
THE LANGUAGE OF MARÍA PAULA ROMO AND OTTO SONNENHOLZNER DURING THE FIRST MONTH OF THE PANDEMIC
}

\author{
EL LENGUAJE DE MARÍA PAULA ROMO Y OTTO \\ SONNENHOLZNER DURANTE EL PRIMER MES DE LA \\ PANDEMIA
}

VIVIANA PALADINES ${ }^{1}$

Recepción: 08 de agosto de 2020 Aceptación: 27 de octubre de 2020

\footnotetext{
${ }^{1}$ Pontificia Universidad Católica del Ecuador, Facultad de Ciencias de la Educación, Facultad de Comunicación, Lingüística y Literatura, estudiante de la Maestría en Pedagogía del Inglés como Lengua Extranjera. Quito,Ecuador.vapaladines@puce.edu.ec
} 



\title{
THE LANGUAGE OF MARÍA PAULA ROMO AND OTTO SONNENHOLZNER DURING THE FIRST MONTH OF THE PANDEMIC
}

\author{
EL LENGUAJE DE MARÍA PAULA ROMO Y OTTO \\ SONNENHOLZNER DURANTE EL PRIMER MES DE LA \\ PANDEMIA
}

Viviana Paladines

Keywords: Women's language, men's language, discourse, pandemic, power

Palabras Clave: Lenguaje de las mujeres, lenguaje de los hombres, discurso, pandemia, poder

\begin{abstract}
There are many differences between women's language and men's language. This continues to be a topic of interest for researchers. Information obtained from investigators has proven

that women have their own language, which differs and it is seen as inferior tot men's language. This study analyzes and describes the differences in the language of two political figures in Ecuador, María
\end{abstract}


Paula Romo and Otto Sonnenholzner, during the early stages of the pandemic, caused by COVID-19.

Based on the observations made on a set of YouTube videos, from interviews and public statements, between March 12th and April 11th, 2020; and through a descriptive analysis, a remark was written, regarding the distinctive elements of gender in speech and language of the aforementioned politicians.

The results seem to indicate that, in this particular scenario, people who watched the videos preferred Sonnenholzner's interventions more than Romo's ones. This was based on the number of likes and views on each one of the videos. This could also be related to the presence of many characteristics of women's language in their speech, and also to the use of conversational strategies by Sonnenholzner, whicht reinforce the demonstration of power over women through speech.

\section{RESUMEN}

Existen varias diferencias entre el lenguaje de la mujer y del hombre. Información obtenida en estudios ha demostrado que las mujeres poseen un lenguaje propio que difiere del lenguaje del hombre y además es visto como inferior. Esta investigación analiza y describe las diferencias en el lenguaje de dos personajes de la política ecuatoriana: María Paula Romo y Otto Sonnenholzner, durante la etapa inicial de la pandemia causada por el COVID-19.

Se realizó un análisis a un set de vídeos de YouTube que incluyen entrevistas y declaraciones públicas entre el 12 de marzo y el 11 de abril de 2020. Con base a las observaciones de este material, se hizo una reseña sobre los elemen- tos distintivos del lenguaje de acuerdo al género de cada uno de los personajes previamente mencionados.

Los resultados indican que, en este escenario en particular, las personas que han visto los vídeos simpatizan con las intervenciones realizadas por Sonnenholzner más que con las de Romo, tomando en cuenta el número de likes y de reproducciones de cada uno de los vídeos. Es posible que también esté relacionado con la presencia de algunas características en el lenguaje de las mujeres. Además, se evidencia el uso de algunas estrategias de conversación por parte de Sonnenholzner que refuerzan la manifestación de poder sobre las mujeres a través del discurso. 


\section{INTRODUCTION}

This article analyzes and describes the language of the government minister, María Paula Romo, and former vice president, Otto Sonnenholzner. It also describes the kind of language they use, and the way they are different from one another, taking into consideration their gender and the characteristics they present in their discourse during the early months of the pandemic, caused by COVID-19, in a set of eight videos from YouTube.

Nordquist (2019) explains that in sociolinguistics and other social sciences, gender refers to sexual identity in relation to culture and society. This could be explained as the roles associated with being male or female, cultural differences that societies assign to people based on their gender, behaviors, personal traits, and social positions. In the same article, Nordquist also points out that, the ways in which words are used. can both reflect and reinforce social attitudes toward gender. An example of this is the continuous request to use neutral words, as much as possible, when it comes to describing occupations, such as chairperson, mailperson, firefighter, salesperson, actor, flight attendant, etc. During the first month of the pandemic, both Romo and Sonnenholzner, were two of the government's officials who took a protagonist role when it came to addressing the citizens and explaining the procedures to follow. Hierarchically, Sonnenholzner's role was at a higher level in his role of vice president.

Holmes \& Meyerhoff (2008) suggest that the fundamental feminist category of gender, as implemented in sociolinguistics, has often included certain political and social assumptions. For them, it is possible to speak of these presumptions as ideologies linked to some dominant ways of conceptualizing gender in Western capitalist contexts, and such gender, should be considered as an institutionalized principle for allocating access to resources.

In Language and Woman's place, Lakoff (1973) states that women experience linguistic discrimination in two ways: in the way they are taught to use language, and in the way general language use treats them. Both tend to relegate women to certain subservient functions: that of sex-object or servant; therefore, certain lexical items mean one thing applied to man and another to women: a difference that cannot be predicted, except with reference to the different roles that sexes play in society. She also mentions that allowing men strong means of expression, which is open to women, further reinforce men's 
position of strength, in the real world (in: ambition, strength, charismatic, willed, and work control); and that, for sure, will be listened, with more attention, to the more strongly and forcefully opinions someone expresses ;and, a speaker unable, for whatever reason, to be forceful in stating his view, is much less likely to be taken seriously. These asseverations can be observed as paralinguistic elements of men's and women's language, in the analysis of the chosen videos.

McEdwards (1985) makes an effort, in trying to explain how some of the characteristics of women's language have actually a positive side, after describing some elements present in woman's language, which are similar to the concepts and skills of successful interpersonal communication and from effective interpersonal communicators. They possess many of the linguistic patterns that our society teaches women-and derides. Some of these characteristics, listed by her, in the article are the ones mentioned by Stewart and D'Angelo (1975). These characteristics are the following:

- Listening and responding to others through eye contact, positive body cues, etc.

- Active perception and thoughtful interpretation of other communication cues.

- Show of humanness, awareness, and acceptance of others, as well as avoidance of negative evaluation.

- Provision of clarity of idea, so as to limit the number of possible interpretation of comments.

- Use of the skills, given above, to handle successfully any conflict springing from opposing content, self-definition, and basic values.

Another of her statements is that, according to several researchers, women have a language of their own, different from and inferior to men 's language. In our society women are taught to: speak softly; to avoid contradicting others; to be submissive in communication; to avoid linguistic assertion and aggression; and to beware of giving cues of strong self-confidence. Several of these characteristics of women's language are agreed upon some authors, who think that a common interpretation of their effect is rich: women's language is symbolic of women's lack of power in our society.

The elements, seen as a positive side of women's language that McEdwards mentions, will be described in the analysis of the videos, as well.

Walsh (1997) presents, in her book "Women, Men and Gender: Ongoing Debates", some of the findings from researchers, that among other things, state the following about men's language: men tend to talk more than women in 
mix-gender groups; interrupt women considerably more than women interrupt men; and use fewer supportive words compared to women.

Both Lakoff (1973) and Walsh (1997) mention that the characteristics of women's language become a part of a woman's life since the early stages, spe- cifically, childhood. One aspect worth mentioning in Walsh's work, in which she quotes Nancy Henley, is that "Gender manifests itself differently in different cultures, but understanding it is crucial to the creation of an equal world for women and men" $(1995$, p. 387).

\section{MATERIALS AND METHODS}

The material used for this research was a set of eight YouTube videos. Four videos belong to María Paula Romo; three belong to Otto Sonnenholzner; and one belongs to both of them, in a press conference. The videos were chosen based on the date, in which the government began to take mitigation actions, as for example: class suspension in the national territory to avoid the spread of COVID-19. The dates on which the videos were posted are between March 12th, 2020 and April 11th, 2020, during the first month of the pandemic.

The method used for this analysis is descriptive, as it aims to describe the language of María Paula Romo and former vice president Otto Sonnenholzner, taking into consideration the paralin- guistic elements present in both women's and men's language.

The set of videos was analyzed, and the observations of the elements mentioned before, as well as the characteristics seen in them, are described.

Observations allow to gather data on behaviors and phenomena, without having to rely on the honesty and accuracy of respondents. This method is often used by psychological, social, and market researchers to understand how people act in real-life situations (McCombes, 2020).

This article describes the differences seen between María Paula Romo's and Otto Sonnenholzner's language and speech. 


\section{RESULTS AND FINDINGS}

Table 1

\begin{tabular}{|c|l|l|c|c|c|}
\hline Number & \multicolumn{1}{|c|}{ Link } & \multicolumn{1}{|c|}{ Date } & Views & Likes & Dislikes \\
\hline 1 & $\underline{\text { María Paula Romo }}$ & March 12th 2020 & 1383 & 6 & 4 \\
\hline 2 & $\underline{\text { Otto Sonnenholzner }}$ & March 14th 2020 & 44120 & 362 & 23 \\
\hline 3 & $\underline{\text { María Paula Romo }}$ & March 18th 2020 & 10543 & 92 & 42 \\
\hline 4 & $\underline{\text { Joined interview }}$ & March 18th 2020 & 7086 & 58 & 19 \\
\hline 5 & $\underline{\text { María Paula Romo }}$ & March 23rd 2020 & 13644 & 14 & 55 \\
\hline 6 & $\underline{\text { Otto Sonnenholzner }}$ & March 29th 2020 & 6848 & 111 & 81 \\
\hline 7 & $\underline{\text { Otto Sonnenholzner }}$ & April 4th 2020 & 22906 & 341 & 293 \\
\hline 8 & $\underline{\text { María Paula Romo }}$ & April 11th 2020 & 4800 & 48 & 36 \\
\hline
\end{tabular}

The previous table contains the information of the videos watched for the analysis. The first thing that comes to our attention, and which is worth mentioning, is the fact that there are significant differences between the number of views on the videos. The video, that has the most views, is the one that belongs to Otto Sonnenholzner, with 44 120 views. It was posted on March 14th, 2020. The second one. with the most views, is another of Sonnenholzner's videos, with 22906 views. It was posted on April 4th. The video that holds the third place is one that belongs to María Paula Romo, with 13644 views posted on March 23rd, 2020.

These number of views, on the videos, could be related to Lakoff's idea that people tend to listen, with more attention, to the one that expresses his opinions more strongly and forcefully, who are ,generally, men. But, there are also some other factors that might have influenced the number of views on the videos, such as the hierarchical role., each one of these political figures held in the government, when the pandemic began. Another factor could be the political stance each one had during the protests that took place in October 2019, all over the Ecuadorian territory, which was caused by the economic measures presented by president Lenin Moreno, in which Romo, as the ministry of government and head of the police forces, received a lot of backlash for the abusive use of force against the protestors, the 
majority of them indigenous people, according to some of the population.

After listening and observing carefully to the videos of the sample, the following elements were recognized in the videos. All of the aspects mentioned and described, are based on Holmes (2013) characterization of both women's and men's languages, and on McEdwards' description of the characteristics of successful interpersonal communication, as well as from effective interpersonal communicators.

The characteristics seen in María Paula Romo's videos are the following:

- $\quad$ She always starts her interventions with a warm greeting to the audience, such as: "Buenas tardes con todos". She also starts following interventions by saying "thank you" to the interviewer "Bueno, muchas gracias." This strategy is used in order to look for equality in the conversation, one of the skills of successful interpersonal communication and from effective interpersonal communicators (McEdwards, 1985) .

(Video \#4, 3:15 minutes and 18:40 minutes)

- The use of an emphatic intonation and the extension of the sound of the vowels while speaking, "Precisamente por lo que usted dice, solamente con el mayooor acceso a datos." When saying the first part of the phrase, she lowers the tone of her voice, to let the interviewer know she agrees with what he says. In the second part of the phrase, she extends the sound of the vowel "o" in "mayor", to stand out the importance of this word in her message. These characteristics are described by Holmes (2013).

(Video \#5, 0:52 seconds)

- In the syntax aspect, Romo generally uses the third person plural to speak about the situation "Lo más importante que podemos hacer es esto, quedarnos en casa". This allows the listener and the viewer to connect with her and feel involved in the situation, she is describing. She also uses echo questions occasionally. These are considered as characteristic elements in women's language, as well (Holmes, 2013).

(Video \#3, 1:55 minutes)

- She empathizes and invites people to follow the guidelines for the pandemic. She explains them, clearly. using a soft tone and her instructions are very specific: "La receta 0 las dos indicaciones más grandes para contener la expansión del coronavirus es quedarse en casa, aislamiento social, es decir guardar la mayor distancia posible de todas las personas y además la mejor limpieza, un perma- 
nente lavado de manos, un lavado de manos bien hecho y la desinfección de las superficies". It could be said that she conveys calmness and reassurance, the way her message is delivered, while showing humanness (McEdwards, 1985).

(Video \#3, 1:57 seconds)

- She accompanies her speech with hand gestures. She moves her hands from one side to the other

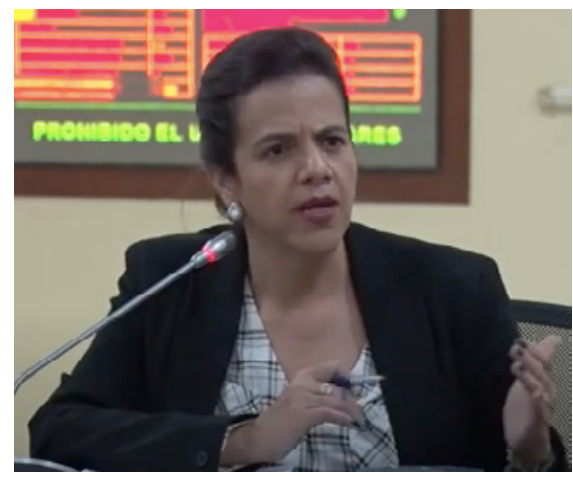

In the case of Otto Sonnenholzner, the following are the observed characteristics in his speech:

- He greets the listeners and the interviewer in a general way. He uses phrases like the following to do so: "Ecuatorianos", reflecting that he is looking to establish power in the conversation, withdrawing himself from the audience by referring to and brings them closer to her upper body. When she mentions different government entities that were involved in the process of elaborating a ministerial agreement, she moves her hand to name each one.

Using body language as a strategy to convey her message (Holmes, 2013).

\section{(Video \# 1, 0:08 seconds)}

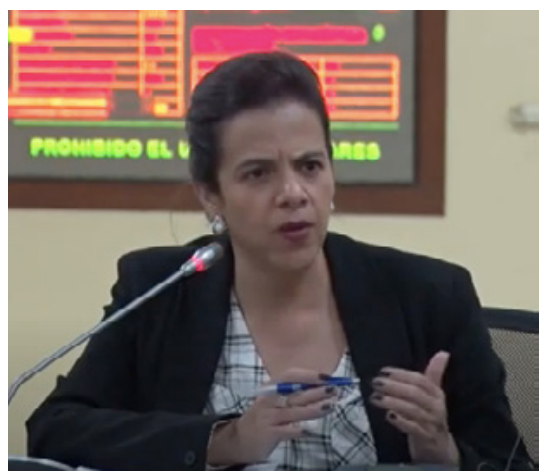

it, in an impersonal way (Holmes, 2013).

(Video \#6, 0:28 seconds)

- The paralinguistic element, present in his speech, is the use of a monotone tone while speaking. In this particular intervention, he is speaking about how international media presented pictures and videos from the health crisis, that was taking 
place in Guayaquil at the beginning of April. He was expressing his apologies for what was happening using the same tone of voice while doing so: "Esta semana hemos sufrido un fuerte deterioro de nuestra imagen internacional y hemos visto imágenes que nunca debieron haber sucedido y por ello como su servidor público, les pido disculpas". Throughout his intervention, he rarely changed his intonation (Holmes, 2013).

(Video \#7, 0:29 seconds)

- In the syntactical aspect of his speech, it is observed that he speaks using the second person singular (Holmes, 2013), most of the time: "La mejor vacuna contra el coronavirus está en tus manos, es quedarte en casa, es cumplir con las medidas de higiene explicadas ya con bastante amplitud, es hacer lo que tienes que hacer, por ti, por tus hijos, por tu familia, por tus abuelos, por tus padres".

(Video \#4, 6:33 minutes)

- When he discusses policies and guidelines for the pandemic, he raises his voice: "Ayer se los dije, la mejor vacuna contra el coronavirus...." It sounds like he might be scolding, in order to convey his message in a stronger way, not showing in his speech, the avoidance of negative evaluation to others (McEdwards, 1985).

(Video \#4, 6:40 minutes)

- During the joint interview, he interrupted María Paula Romo and the interviewer, in five different occasions, in order to reassure or emphasize her and his ideas: "Un tema, un tema, un tema adicional para agregar adicionalmente hay una restricción de movilidad...", "sí, así es" (while Romo was speaking). These are some of the interruptions that are seen, in this press conference, in which he was not listening nor responding to others, neither through eye contact nor through positive body cues (McEdwards, 1985).

(Video \# 4, 5:44 / 11:48 / 13:30 / 13:38 / 22:47 minutes)

- He does not use body language to accompany his ideas: He did not respond to others through eye contact or positive body cues (McEdwards, 1985). When explaining some of the government's decisions to close borders, he kept both of his arms and hands, in a resting position, on top of the desk.

(Video \#2, 1:22 minutes) 


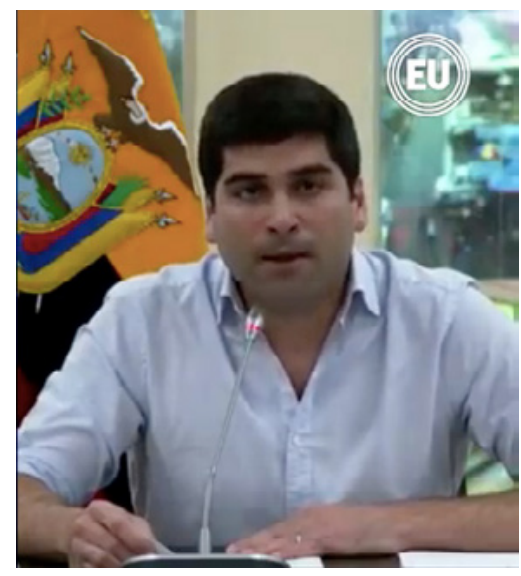

As mentioned before, the number of views, on each one of the videos, is something that called our attention. Otto Sonnenholzner's videos have more views than the ones that belong to María Paula Romo. They also have more likes.

This could make one wonder if it has something to do with the fact that, in this situation, the use of stronger means of expression on his side reinforce men's position of strength, in the world, and makes him more likely to be taken seriously by people, in general. As opposed to Romo, who demonstrates more empathy in her statements She might be seen as a person who could be less likely to be taken seriously.

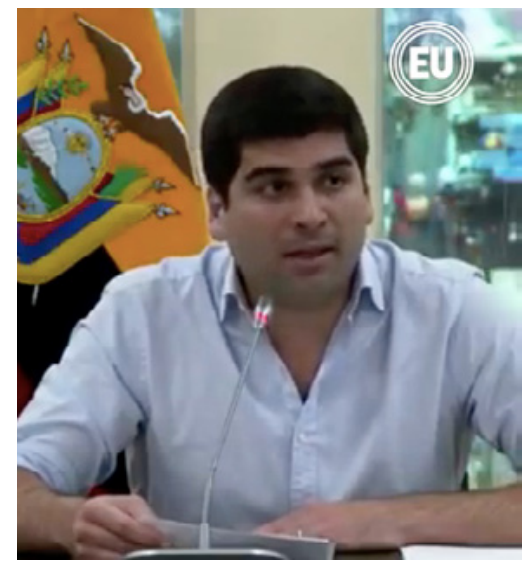

However, after listening to Romo's interviews, a sense of reassurance and calmness are transmitted in her speech. She seems more approachable and connected to the audience. She shows depth in knowledge and accuracy. She is not afraid of letting the audience know that, if for any reason, she does not have precise information, she is willing to look into it and share it later. These are some characteristics of women's language.

Using the information obtained in this analysis, it could be said and confirmed that many of the ideas explained by Lakoff, are still current in 2020. As she explained, women in our politics in Ecuador, are marginal to the serious concerns of life, which are preempted by men. 


\section{CONCLUSIONS}

The following are some of the conclusions obtained in this analysis.

Both María Paula Romo and Otto Sonnenholzner are able to express their ideas, thoughts, and facts in a clear way that is comprehensible for the audience, as seen on the videos. During the first months of the pandemic, they were usually the ones who addressed the Nation, explaining the guidelines and precautions mandated for public safety. They were able to communicate in an effective and eloquent manner, which is one of the characteristics of the skills of successful interpersonal communication and from effective interpersonal communicators.

It could also be said that, according to the number of views and likes on the videos, it might seem that Sonnenholzner had more popularity than Romo. In times of crisis, people rely on their leaders to tell them what to do and what to expect. Because of the vulnerability of the matter, people are likely to follow or pay more attention to the one that speaks in a stronger way. According to the publication: "Why People Follow the Leader: The Power of Transference", (2014) on Harvard's Business Review, followers' motivations fall into two categories rational and irrational - , and for the most part, these motivations arise from the powerful images and emotions in our unconsciousness, which we project onto our relationships with leaders.

This could mean that in an unconscious level, people relied on the projection of Sonnenholzner's images and emotions, because he presented a strong façade, while referring to COVID-19, transmitting a sense of security and safety.

Regarding the elements of women's language, it is important to mention that, the paralinguistic elements in Romo's speech, make her seem like a more approachable and empathetic person, evidenced in: her tone, the choose of words, and her body language. According to McEdwards (1985), these characteristics of women's language can be interpreted as a virtue in communication.

Sonnenholzner uses conversational strategies, that allow him to demonstrate his authority, to the viewers and listeners. In the article "'He Who Speaks, Controls' the Conversation. But Not If You Use This Tactic", Schools (2019) explains that people who are influential, tend to speak more in a conversation. Whoever is smarter, more experienced, louder, more passionate - all the different ways power manifests - whoever is 
more powerful, speaks more in any given conversation, whether it's between: friends, partners, teammates, clients, opponents, and so on. This person. is the one, who tends to control the conversation and monopolizes the time. An example of this behavior is seen in the way in which: Sonnenholzner raises the tone; he speaks in order to scold the viewers; and when he interrupts the interviewer and María Paula Romo, in order to reinforce his or even her thoughts and ideas.
Many of the elements in both women's and men's language, which were previously described, were observed in the videos. In a time of uncertainty, in which everything was new and scary, as it was during the first months of the pandemic, both Romo and Sonnenholzner were able to communicate in an articulate and adequate fashion. They were the government officials, who were most likely to address the citizens to inform about the situation. 


\section{REFERENCES}

United Nations (2003) Ecuador's Gender Equality Mechanisms Need Real Power to Achieve Positive Results, Say Experts in Women's Anti - Discrimination Committee | Meetings Coverage and Press Releases. (n.d.). Https://Www.Un.Org/ Press/En/2003/Wom1411.Doc. Htm. Retrieved October 15, 2020, from https://www.un.org/press/ en/2003/wom1411.doc.htm

Holmes, J. (2013). An Introduction to Sociolinguistics, 4th Edition (Learning About Language) (4th ed.). Routledge.

Holmes, J., \& Meyerhoff, M. (2008). The Handbook of Language and Gender. Wiley. Retrieved from: https:// www.google.com/books/edition/_tQqAbxMAmfQC?hl=en\&gbpv $=0$

Hryniewicz, L. G. C., \& Vianna, M. A. (2018). Mulheres em posição de liderança: obstáculos e expectativas de gênero em cargos gerenciais. Cadernos EBAPE. $B R$, 16(3), 331-344. https://doi. org/10.1590/1679-395174876

Lakoff, R. (1973). Language and Woman's Place. Language in Society, 2(1), 45-80. Retrieved July 3, 2020, from www.jstor.org/stable/4166707
McEdwards, M. G. (1985). Women's Language: A Positive View. The English Journal, 74(3), 40. https://doi. org/10.2307/817103

Nordquist, R. (2019, July 3). What Is Gender as Defined by Sociolinguistics? ThoughtCo. Retrieved from: https://www.thoughtco. com/gender-in-sociolinguistics-1690888\#:\%7E:text $=\ln \% 20$ sociolinguistics $\% 20$ and $\% 20$ other\%20social,reinforce\%20social\%20attitudes\%20toward\%20 gender.

Schools, D. (2019, May 12). 'He Who Speaks, Controls' the Conversation. But not if you use this tactic. Medium. Retrieved from: https:// entrepreneurshandbook.co/hewho-speaks-controls-the-conversation-but-not-if-you-use-thistactic-ec3e49a3ba91

Walsh, M. R. (1996). Women, Men, and Gender: Ongoing Debates (0 ed.). Yale University Press.

Why People Follow the Leader: The Power of Transference. (2014, August 1). Harvard Business Review. https:// hbr.org/2004/09/why-peoplefollow-the-leader-the-power-oftransference 